\title{
Geochemical composition and genesis of brines from two Upper Permian salt deposits, Germany
}

\author{
MiCHAEL SCHRAMM ${ }^{1}$ \\ ${ }^{1}$ Federal Institute for Geosciences and Natural Resources \\ (BGR), Stilleweg 2, 30655 Hannover, Germany; \\ michael.schramm@bgr.de
}

Brines were detected in Upper Permian (Zechstein) salt structures, $666 \mathrm{~m}^{3}$ (1979-2012) in Gorleben and $3312 \mathrm{~m}^{3}$ (1907-2017) in Morsleben, mainly linked to anhydrite bearing salt rock formations and to lithological boundaries.

In the Gorleben site, all investigated solutions are at least halite and anhydrite saturated. The majority of the brines (ca. $297 \mathrm{~m}^{3}$ ) originate from the z3OSM. In the Jänecke diagrams (at $25^{\circ} \mathrm{C}, 35^{\circ} \mathrm{C}$ ), they plot in the carnallite stability field or at the edge to the kieserite field. Further, they are characterized

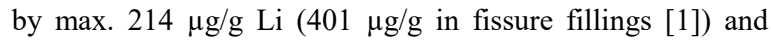
max. $6778 \mu \mathrm{g} / \mathrm{g} \mathrm{Br}$. The z3HA brines (ca. $250 \mathrm{~m}^{3}$ ) plot in the carnallite field or at the edges to the kieserite, bischofite or sylvite stability field; $\leq 9.40$ wt. $\% \mathrm{Mg}$ and $1721-3680 \mu \mathrm{g} / \mathrm{g}$ $\mathrm{Br}$ are typical values. At the lithological change from $\mathrm{z} 2$ to $\mathrm{z} 3$, ca. $40 \mathrm{~m}^{3}$ brine were observed. These brines can be attributed to the kieserite, bischofite or the boundary to the carnallite and kieserite stability field. $\mathrm{CaCl}_{2}$ (fictive) and a low $\mathrm{K} / \mathrm{Mg}$ ratio of 0.005 is typical. The z3AM brines plot in the stability field of kieserite and the $\mathrm{z} 3 \mathrm{BK} / \mathrm{BD}$ brines in the field of carnallite. With exception of technical solutions, all captured Gorleben brines are of salt dome internal origin, developed during diagenesis and in parts by subsequent rockfluid interaction. Frequently high $\mathrm{Li}$ concentrations in the brines indicate probably interaction with phyllosilicate bearing strata.

Most of the Morsleben brines $\left(3082 \mathrm{~m}^{3}\right)$, detected in the metamorphic overprinted potash seam z2SF, are halite, anhydrite, gypsum, sylvite and kainite saturated. $\mathrm{The} \mathrm{Rb} / \mathrm{Br}$ [2] and $\mathrm{Li} / \mathrm{Mg}$ ratios indicate groundwater dilution in relation to evaporated seawater $(\leq 3 \mu \mathrm{g} / \mathrm{g} \mathrm{Li})$ [1]. These brines show mainly groundwater and minor signatures of dissolved salt rocks. The brines from the z3HA $\left(230 \mathrm{~m}^{3}\right)$ are halite, anhydrite, carnallite and sylvite saturated. These brines show $\mathrm{Rb} / \mathrm{Br}$ ratios of typical marine origin, 2259-3429 $\mu \mathrm{g} / \mathrm{g} \mathrm{Br}$ and $\mathrm{Li} / \mathrm{Mg}$ ratios partial slightly enriched in $\mathrm{Li}(\leq 24 \mu \mathrm{g} / \mathrm{g})$, which are comparable to high-evaporated relictic seawater, or metamorphic brines of salt structure internal origin [1].

[1] Mertineit \& Schramm (2019) Minerals 9, 766; doi: $10.3390 / \min 9120766$.

[2] Mattenklott (1995) Kali und Steinsalz, 11, 341-344. 